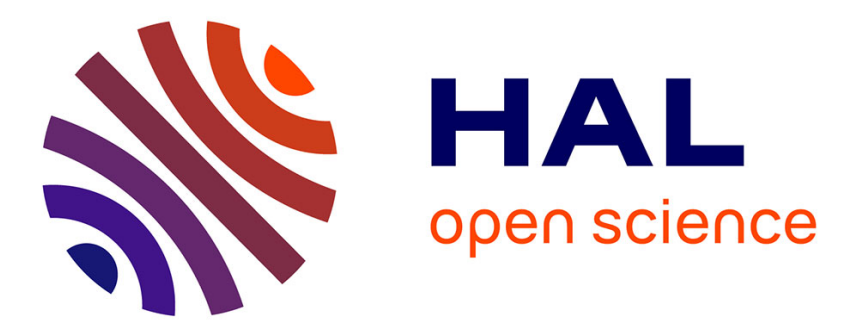

\title{
How should energy be defined throughout schooling?
}

Manuel Bächtold

\section{To cite this version:}

Manuel Bächtold. How should energy be defined throughout schooling?. Research in Science Education, 2017, 48 (2), pp.345-367. 10.1007/s11165-016-9571-5 . hal-01521131

\section{HAL Id: hal-01521131 https://hal.science/hal-01521131}

Submitted on 11 May 2017

HAL is a multi-disciplinary open access archive for the deposit and dissemination of scientific research documents, whether they are published or not. The documents may come from teaching and research institutions in France or abroad, or from public or private research centers.
L'archive ouverte pluridisciplinaire HAL, est destinée au dépôt et à la diffusion de documents scientifiques de niveau recherche, publiés ou non, émanant des établissements d'enseignement et de recherche français ou étrangers, des laboratoires publics ou privés. 
to appear in Research in Science Education

\title{
How should energy be defined throughout schooling?
}

\author{
Manuel Bächtold \\ LIRDEF (EA 3749), Universités Montpellier et UPVM
}

\begin{abstract}
:
The question of how to teach energy has been renewed by recent studies focusing on the learning and teaching progressions for this concept. In this context, one question has been, for the most part, overlooked: how should energy be defined throughout schooling. This paper addresses this question in three steps. We first identify and discuss two main approaches in physics concerning the definition of energy, one claiming there is no satisfactory definition and taking conservation as a fundamental property, the other based on Rankineâs definition of energy as the capacity of a system to produce changes. We then present a study concerning how energy is actually defined throughout schooling in the case of France by analyzing the national programs, physics textbooks, and the answers of teachers to a questionnaire. This study brings to light a consistency problem in the way energy is defined across school years: in primary school, an adapted version of Rankineô definition is introduced and conservation is ignored; while in high school, conservation is introduced and Rankineô definition is ignored. Finally, we address this consistency problem by discussing possible teaching progressions. We argue in favor of the use of Rankineôs definition throughout schooling: at primary school, it is a possible substitute to studentsô erroneous conceptions; at secondary school, it might help students become aware of the unifying role of energy and thereby overcome the compartmentalization problem.
\end{abstract}

Keywords: definition of energy, teaching progression, conservation of energy, Rankine

\section{Introduction}

Energy is a fundamental concept of physics that enables the explanation and prediction of many phenomena and contributes to the unification of the various branches of physics. For this reason, it can be considered one of the ñbig ideasò that should be taught in school (National Research Council, 1996, p. 115, Lee \& Liu, 2010, Eisenkraft et al., 2014). However, energy is also a difficult concept to understand and to master. It is highly abstract (Warren, 1982, Millar, 2005), and its meaning in physics differs from that found in everyday life (Solomon, 1983, Lijnse, 1990). There is a subtle distinction among sources, forms and modes of transfer of energy (e.g., work and heat being occasionally mistaken as forms rather than modes of transfer of energy, Cotignola et al., 2002, Jewett, 2008b, Papadouris \& Constantinou, 2011). Energy must not be confused with other closely related quantities such as force, temperature, power, and entropy. For example, force and energy are often confused (Watts, 1983, Trellu \& Toussaint, 1986), as are heat and temperature (Lewis \& Linn, 1994, Harrison et al., 1999). Finally, the concept is inseparable from the principle of energy conservation, and few students at the end of secondary school can apply this principle correctly (Duit, 1981, Driver \& Warrington, 1985, Solomon, 1985, Trumper, 1990, Neumann et al., 2013). How energy should be taught, therefore, remains a topical question. Since the 1980s, many teaching strategies have been proposed and discussed (for an overview, see Millar, 2005, Doménech et al., 2009, Authors, 2014a). 
More recently, it has been highlighted that students cannot learn about energy in one attempt but must follow several conceptual steps. Some authors have attempted to determine empirically studentsô actual ñlearning progressionò (i.e., the conceptual steps students are actually following across school years); in the light of these studies, these authors and others have also discussed what might be the most adequate teaching progression throughout schooling (i.e., what features of energy should be taught, and how, at each grade) (Liu \& McKeough, 2005, Lee \& Liu, 2010, Nordine et al., 2011, Colonnese et al., 2012, Neumann et al., 2013, Lacy et al. 2014, Duit, 2014, Authors, 2014b). There is an important question in this new context that has been addressed minimally to date (Colonnese et al., 2012, Authors, 2014b): should teachers provide their students with a definition of energy, and, if so, what definition should they provide and at what level of the science curriculum should it be provided? This question is problematic insofar as the very question of how to define energy remains debated in the field of physics. Although the concept of energy is now used in all domains of physics, some physicists, following Feynman, believe that ñn physics today, we have no knowledge of what energy isò $(1963,4.2)$; thus, no satisfactory definition of it would be available. However, this view is not endorsed by all physicists, and in the field of physics education, several approaches have been proposed concerning how energy could be defined (Lehavi et al., 2012). However, this question of the definition of energy has hardly been discussed from the perspective of a teaching progression for energy.

This paper addresses the question of how to define energy throughout schooling in three steps. In the first step, we examine more carefully whether and how energy can be defined in the field of physics. Two main approaches are distinguished: the conservation approach and Rankineôs approach. In the second step, we present a study concerning how energy is actually defined throughout schooling (in the case of France) and whether one or both approaches are employed. This case study brings to light what we call the ñconsistency problem. ÒIn the third step, we address this problem by investigating the way energy could be defined in a coherent manner across school years.

\section{What does physics tell us about energy?}

Before studying how energy is or could be defined in school (sections 3 and 4), it is useful to clarify what physics tells us about energy, i.e., how it can be described and what possible definition of it can be given.

\subsection{Nominal and operational definitions of energy}

To begin with, we can spell out the points of agreement concerning the description of energy in physics:

1) Energy is a variable state quantity (i.e., a quantity associated with a physical system and determined by its state).

2) In SI Units, energy is measured in joules (J).

3) There are different forms (or types) of energy (kinetic, potential, thermal, chemicalé ).

4) Energy can be converted from one form into another.

5) Energy can be transferred from one system to another.

6) There are different means of transferring energy (work, thermal transfer, lighté ).

7) Energy can be dissipated (or degraded). 
8) Energy is a conserved quantity (i.e., it can be neither created nor destroyed). Two additional features of energy must be expressed in a negative manner:

9) Energy cannot be directly measured (i.e., it can be evaluated only indirectly by means of the measurement of other quantities which arise in the mathematical formula of given forms of energy).

10) There is no mathematical formula for energy in general (although formulas do exist for the different forms and modes of transfers of energy).

Finally, it must be stressed that a definition of energy, which was given by Rankine in the middle of the $19^{\text {th }}$ century, is endorsed by some physicists but rejected by others:

11) Energy is the capacity of a system to do work.

To clarify the status of the different points expressed above, we can make use of the distinction between ñominalò and ñoperationalò definitions of physical concepts. This distinction was proposed by Margenau (1950) and expressed by Galili and Lehavi (2006, p. 524) as follows: ñA nominal definition seeks to establish the meaning of a concept by relating it to other concepts and by listing its characteristic features; it matches theory. An operational definition, on the other hand, defines the concept in terms of a particular measurement, indicating the apparatus, the conditions of measurement, and possibly, also, the unitsò.

In the case of energy, two points mentioned above, namely points 2 and 9, contribute to an operational definition of this concept. The other points can be related to its nominal definition. Let us consider them one by one. Point 1 can be viewed as a nominal definition but as a quite general one; it does not differentiate energy from other quantities because there are several variable state quantities. Points 3 to 8 correspond to a set of characteristic features of energy. Although they describe the properties of energy, they do not say what this quantity is or what it represents. In this respect, they do not constitute what we may call a ñformalò nominal definition of energy. On the contrary, point 11 (Rankineôs definition) is such a definition. However this definition is controversial.

The disagreement on Rankineôs definition is a strong one. This point leads us to distinguish two main approaches with respect to the definition of energy. Let us present the various arguments favoring and against each of them.

\subsection{Conservation as a fundamental property}

A first approach supports the points that there is no satisfactory formal definition of energy and that we take conservation as a fundamental property. This approach is endorsed by Feynman (quoted above), in line with another famous scientist, Poincaré (1968 [1902]), who claimed, ñAs we cannot give energy a general definition, the principle of conservation of energy simply means that there is something that remains constant.ò

Let us consider the statement ñenergy is what has the property of being conservedò. This can be viewed as a nominal definition. However, is this definition sufficient? In spite of the fact that conservation is a fundamental property of energy, it is unable to differentiate it from other quantities. For example, linear momentum and angular momentum are also conserved quantities. Surprisingly, the fact that conservation is not a discriminating property has hardly been emphasized in the literature.

A possible means of discriminating energy from other conserved quantities is to specify the whole set of its properties, namely points 3 to 8 . This set of properties constitutes a more 
complete nominal definition of energy and has the advantage of differentiating it from all other quantities. Nevertheless, it may still appear unsatisfactory insofar it does not explain what this quantity is or what it represents.

\subsection{Rankineô definition}

The second approach consists of making use of Rankineâs definition (1855) of energy as the ñcapacity of a system to do workò (where ñworkò refers to the quantity defined in mechanics in terms of force and displacement of a system). Let us stress that this formal nominal definition was never fully accepted. Today, only one part of the academic textbooks in physics mentions it. As an example, Hobson (2004) surveyed 22 introductory physics textbooks and found that 6 defined energy as the ñapacity of a system to do work.ò During the last three decades, the relevance of this definition has been debated. Note that this debate has occurred in the physics education literature, and not merely in that of theoretical physics. Although the authors contributing to this debate are ultimately concerned with the question of how to make sense of energy to students, they also discussed Rankineâs definition from the point of view of physics. In the remainder of this section, we discuss this definition only from this point of view. We return in section 4.2 to the relevance of this definition from the point of view of energy teaching.

According to Warren $(1982,1991)$, the notion of form of energy and the conservation property have no meaning without the definition of energy as the capacity of a body for doing work. For instance, a system can be said to have kinetic energy equal to $1 / 2 m v^{2}$ only if one conceives the possibility that this system can transfer energy to another system without dissipation by means of work. Indeed, the value $1 / 2 m v^{2}$ is obtained by calculating the work produced by the system if brought to rest with respect to a given observer (Warren, 1991, p. 8). Similarly, McIldowie (2004, pp. 213-214) argues, ñEnergy and work form a duality. A system can be said to possess energy, and when energy is transferred, work is done. A true description of what goes on in any transfer of energy inevitably involves both concepts. [é ] All energy is potential work.ò As Hobson (2004, p. 260) writes, ñQuantitatively, a systemôs energy is the amount of work it can do.ò

It must be emphasized that Rankine introduced his definition at the same time as he and Thomson proposed to explain the conversion processes in terms of energy transformation and conservation (i.e., in the 1850s). This historical fact is significant. Indeed, Rankineôs definition provided a simple justification for viewing different quantities, say $A$ and $B$, as instances of the same quantity, as ñforms of energyò (e.g., kinetic energy, thermal energyé ): quantities $A$ and $B$ can be conceived as instances of the same quantity because some value $a$ of $A$ and some value $b$ of $B$ are equivalent with respect to the capacity of the systems under consideration to produce the same physical changes (e.g., the increase of temperature or the change in velocity of a body). Identifying these quantities as forms of energy in turn enabled describing the conversion processes as transformations of energy with the total amount of energy being conserved.

Sexl (1981), Duit (1981), and Trumper (1991) challenge Rankinê̂ definition by claiming that it is refuted by the second law of thermodynamics. This argument is expressed by Sexl (1981, p. 287) as follows: ñThe statement that ánergy describes the capacity of a system to perform workô is not satisfactory because it cannot be used in thermodynamics. Thus, the 
internal energy of a system cannot be transformed completely into work. òLet us make the last step of this argument explicit: if the energy of a system cannot entirely be transformed into work, this energy cannot be equated with the work the system is actually able to produce.

Warren (1982) and Hobson (2004) both reply that Rankineôs definition is not a claim that, in all conditions, the whole amount of energy of a system can be used to produce work. Indeed, this is not possible in cyclic processes; according to the second law of thermodynamics, this definition means rather that we can always imagine ideal conditions for which this is possible. As Hobson (2004, p. 260) stresses, ñThe definition should be understood as referring to the amount of work a system could do under ideal conditions.o

Another objection has been advanced by Duit (1981, 2014) concerning the scope of Rankineôs definition: it is not sufficiently general in its reference to merely mechanical effects, i.e., effects in terms of work. According to Duit (1981, pp. 292-293), ñthe energy concept as expressed in the above definition [i.e., Rankine $\hat{Q}$ definition] is limited to mechanics. [é ] this energy concept does not possess universal validity (energy is not only the ability for doing work but also a precondition for many other processes such as heating, lighting etc.).ò

A possible answer amounts to the claim that any type of effect in principle can be converted into a mechanical effect; hence, its value can be expressed in terms of work. There is another means of evading this objection, which consists of slightly modifying the definition, replacing ñworkò with ñtransformationsò (Doménech et al., 2007) or ñchangesò (Bunge, 2000, Authors, 2014a) $\ddot{i}$ these two terms being understood tacitly as referring to physical transformations and changes.

With respect to this definition in terms of ñchanges, ò energy acquires a very wide scope: it is applicable in all the domains of physics. As such, it is in accordance with the unifying role of energy, which contributed, in the middle of the $19^{\text {th }}$ century, to making energy a fundamental concept in the field of physics. As emphasized by Harman (1982, p. 58), ñthe fundamental status of energy derived from its immutability and convertibility and from its unifying role in linking all physical phenomena within a web of energy transformations.ò

Against Rankineôs definition in terms of ñchanges,ò Duit (1981, p. 293) argues it is not able to distinguish energy from other quantities: ñThe ability to bring about changes can also justifiably be attributed to a number of other physical concepts (for example, force and torque).ò

There is a possible answer to this argument. The physical changes associated with a force or a torque are simultaneous to their application, whereas the physical changes a system can produce by virtue of its energy are only potential. For instance, in some cases, if a force is applied on a body, the latter is set in motion. The application of the force does not endow the body with some capacity to move, it makes it move at the very time it is applied. Therefore, only energy can be said, strictly speaking, to describe the ñcapacityò or ñabilityò of the system to produce physical changes.

More recently, Coelho (2014) has stated another argument against Rankineôs definition of energy as ñthe capacity of doing work.ò According to him, the problem with this definition is that it leads to a substantialist conception of energy (2014, p. 1362): ñAnother common definition of energy in textbooks is ánergy is the capacity of doing work.ôThe subject of the 
previous sentence is energy. Therefore, energy has this ability. If this is the case, then energy must be something real. So real, that it is able to act, namely to do work.ò

This last objection can be addressed by answering that Coelho misinterprets the sentence ñenergy is the capacity of doing workò by changing it into the sentence, r̃energy has the capacity of doing work. ò Now, the sentence ñenergy is the capacity of doing workò should be considered a shortened version of ñenergy is the capacity of a system to do work.ò The definition expressed in this manner does not compel us to hypostatize energy; rather, it describes this quantity as the property of a system, and only the system is something able to do work.

\subsection{Discussion}

Thus far, we have distinguished two main approaches with respect to the definition of energy: the conservation approach and Rankineô approach. While both approaches have been subject to various objections in the literature, the second one was argued to have more advantages. Let us recall that the conservation approach faces a major problem: conservation is not a discriminating property (i.e., other quantities are also conserved). As for Rankineôs definition it offers a way to grasp the meaning of energy: it helps to understand what makes it different from other conserved quantities and provides a justification for viewing the different quantities as being instances of the same quantity, as being ñforms of energy.ò Moreover, this definition has a very wide scope making it valid in all the domains of physics, in accordance with the unifying role of energy. Furthermore, it appears that all the objections against Rankineôs definition can be challenged. The advantages of this definition may provide arguments in favor of introducing it at school in the frame of energy teaching. Before considering these arguments (section 4), let us turn to what is currently done at school.

\section{The consistency problem: a case study}

The question of how to define energy throughout schooling has received little attention so far. No clear proposal has been made in the science education literature. It is likely therefore that the authors of the national programs as well as teachers do not consider this question either. Given the fact the very definition of energy is debated in the field of physics, one can expect there is no consistency in the way energy is defined across years of instruction. This might cause difficulties for students in their learning of energy, what has not been stressed to date in the literature. So as to better understand what we shall call the ñconsistency problemò, it would be helpful to know how energy is actually defined throughout schooling. Is one of the two approaches favored in school? If so, is it the case across grade levels? Or is there a change of approach depending on the grade? We propose to examine these questions by carrying out a survey in one country, namely France. One reason for this choice is that the French middle school program makes an explicit reference to Rankineôs definition.

\subsection{Method, part 1}

We examined the French national programs from grades 3 to 12. It must be stressed that teachers in France are compelled to follow the programs precisely. Although they can choose their pedagogical methods in some respects, they officially have no freedom to change either the content to be taught or the teaching progression described in the programs. Therefore, the 
analysis of these programs provides us with an insight concerning how energy is defined throughout schooling in France. We also examined a selection of physics textbooks from grades 3 to 12 (extending the study presented in Authors, 2014b). These textbooks suggest a variety of possible approaches to interpreting the programs by giving specific formulations of the items of the programs and additional content. These formulations correspond to possible ways teachers themselves interpret and implement the programs. Moreover, being read and used by teachers, the textbooks influence teachersô approach to teaching. Hence, analyzing these textbooks provides a complementary insight on how energy is actually defined across years of instruction.

This analysis consisted in searching for occurrences of formal definitions of energy, but also for statements referring to the various features of energy and providing thereby an indirect definition of energy. We checked systematically if there were statements in line with Rankineôs definition and formulations of the conservation property. We characterized these definitions as being either nominal or operational (see section 2.1). We also made used of one subcategory of nominal definitions, namely ñexical definitionsò, which are described by Galili and Lehavi (2006, pp. 525-526) as including ñfigurative statements, ónon-formal termsô [é ] casual expressions only vaguely related to theory [and] concepts [é ] related to common experiences, sensations, or ideasò.

\subsection{Outcomes, part 1}

We present in Table 1 the definitions of energy provided by the French national programs from grades 3 to 12 and a selection of physics textbooks $(N=28$, see references in Appendices, Table A1). We also report the cases in which conservation of energy is mentioned. Note that energy is not mentioned in the programs of physics and chemistry in grades 6 and 10 and that energy is only a secondary item in those of grades 7 and 8 . As there has been found no difference with respect to the definition of energy and conservation of energy between grades 3 to 5 and between grades 7 and 8, the outcomes concerning these grades are presented in a single line of the table of Table 1 .

Table 1

Definitions of energy provided by the French national programs and a selection of textbooks

\begin{tabular}{|c|c|c|}
\hline & French national programs & Physics textbooks $(N=28)$ \\
\hline Grades 3 to 5 & $\begin{array}{l}\text { No formal definition, but the } \\
\text { following statement: } \\
\text { ñThe use of an energy source } \\
\text { is necessary to heat, to light, to } \\
\text { set in motion.ò } \\
\text { Conservation of energy is not } \\
\text { mentioned. }\end{array}$ & $\begin{array}{l}(N=8) \\
5 \text { textbooks out of } 8 \text { provide a definition: } \\
\text { ñEnergy is what enables to heat (calorific energy), to } \\
\text { produce light (luminous energy), to produce electricity } \\
\text { (electrical energy) and to set in motion (mechanical } \\
\text { energy).ò } \\
\text { ñEnergy: possibility for matter or an object to provide heat, } \\
\text { light or motionò } \\
\text { ñEnergy makes it possible for an object to set itself in } \\
\text { motion, to produce light or heat.ò } \\
\text { ñEnergy can modify the state of things, make them change } \\
\text { their shape, make them move, or make them work.ò } \\
\text { ñEvery object of our everyday environment needs energy to } \\
\text { work [é ] energy can be used to light (lamp), to set in }\end{array}$ \\
\hline
\end{tabular}




\begin{tabular}{|c|c|c|}
\hline & & $\begin{array}{l}\text { motion (car, train, boat), to move, to heat (fire, radiator), to } \\
\text { communicate (phone).o } \\
\text { No textbook mentions conservation of energy. }\end{array}$ \\
\hline \multirow[t]{2}{*}{ Grades 7 to 9} & \multirow{2}{*}{$\begin{array}{l}\text { Two definitions are provided } \\
\text { in the introduction of the } \\
\text { physics and chemistry } \\
\text { programs (grades } 6 \text { to 9): } \\
\text { ñEnergy appears as the } \\
\text { capacity of a system to } \\
\text { produce an effect.ò } \\
\text { ñThe energy possessed by a } \\
\text { system is a quantity which } \\
\text { characterizes its ability to } \\
\text { produce actions.ò } \\
\text { Conservation of energy is not } \\
\text { mentioned, }\end{array}$} & $\begin{array}{l}\text { Grades } 7 \text { and } 8(N=3) \\
1 \text { textbook out of } 3 \text { provides a definition: } \\
\text { - ñenergy: an object has energy if it can produce actions or } \\
\text { effectsò } \\
\text { No textbook mentions conservation of energy. }\end{array}$ \\
\hline & & $\begin{array}{l}\text { Grade } 9(N=7) \\
2 \text { textbooks out of } 7 \text { provide a definition: } \\
\text { ñScientists define energy as the capacity to produce workò } \\
\text { (notice that no definition of óvorkôis provided in this } \\
\text { textbook). } \\
\text { ñEnergy: physical quantity which is conserved. An object } \\
\text { which has energy can produce actions: heat, light, set in } \\
\text { motion, etc.ò } \\
3 \text { textbooks out of } 7 \text { mention conservation of energy: } \\
\text { ñEnergy: physical quantity which is conservedò } \\
\text { ñThe most remarkable characteristic of energy is that is it } \\
\text { always conserved.ò } \\
\text { ñEnergy can neither be created nor lost. Energy is } \\
\text { conserved.ò }\end{array}$ \\
\hline $\begin{array}{l}\text { Grade } 11 \\
\text { scientific } \\
\text { pathway } \\
\text { (note: around half } \\
\text { of students at high } \\
\text { school follow this } \\
\text { particular } \\
\text { pathway) }\end{array}$ & $\begin{array}{l}\text { No definition } \\
\text { An item of the program: } \\
\text { p̧principle of conservation of } \\
\text { energyò }\end{array}$ & 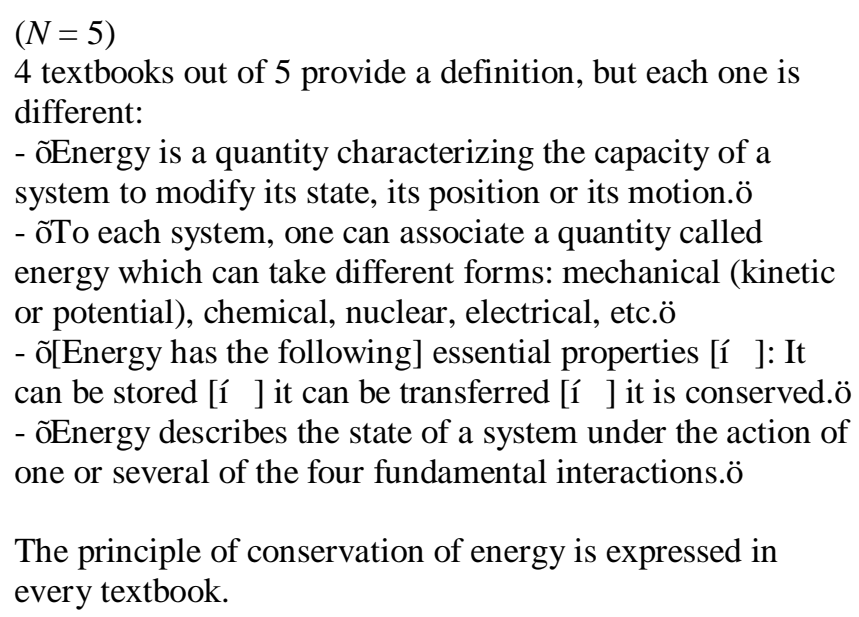 \\
\hline $\begin{array}{c}\text { Grade 12 } \\
\text { scientific } \\
\text { pathway }\end{array}$ & $\begin{array}{l}\text { No definition } \\
\text { Conservation of energy is not } \\
\text { mentioned. }\end{array}$ & $\begin{array}{l}(N=5) \\
\text { No textbook provides a definition. } \\
1 \text { textbook out of } 5 \text { mentions conservation of energy: } \\
\text { - ñThe total energy of an isolated system is conserved.ò }\end{array}$ \\
\hline
\end{tabular}

Note: the parentheses ñné )ò are those of the authors, whereas the brackets ñ]é ]ò are added by us.

In primary school (grades 3 to 5), a majority of textbooks provide a definition of energy corresponding to an adaptation of Rankineôs definition in terms of ñchanges.ò These definitions can be considered lexical definitions. They are partly in line with a sentence that can be found in the national programs, which nonetheless refers to ñenergy sourceò rather than to ñenergy.ò Some of them retain the notion of capacity (e.g., ñpossibility,ò ñmakes it 
possibleò); the others remove this element of Rankineô definition. Note that one definition is reifying energy by making it the subject of actions (ñenergy can modify the state of thingsé ò). This definition, disputed by Coelho, is in fact a fallacious transformation of Rankineôs original definition (see above, section 2.3). Concerning conservation of energy, neither the national program nor the textbooks mention it in primary school.

In middle school (i.e., grades 7 to 9), the national programs introduce Rankineôs definition in terms of ñ changesò (using the expressions ñeffectsò or ñactionsò rather than ñchangesò). A few textbooks follow the program in this respect and provide this definition or an adaptation of it. Although there is no reference to conservation of energy in the national programs in these grades, some textbooks take the initiative to mention this property and present it as fundamental.

In high school (grades 11 and 12), the national programs do not refer to Rankineôs definition anymore or to any other definition of energy. Nonetheless, in grade 11, most of the textbooks provide a nominal definition. The proposed definitions are of various types: Rankineôs definition, but also definitions in terms of the properties of energy and a definition referring to the fundamental forces of physics. The fact that these textbooks propose a nominal definition may be explained by the fact that energy is presented as a key concept in the national program of physics and chemistry in this grade. In grade 12, there is no textbook providing a definition.

The principle of energy conservation is central in grade 11, both in the national program and in the textbooks. However, no further reference is made to this principle in grade 12. Few textbooks present conservation as the fundamental property of energy.

\subsection{Method, part 2}

Our goal being to obtain a quantitatively significant picture of how energy is actually defined in school, we chose to make use of a questionnaire. To build a meaningful questionnaire, we attempted to anticipate the possible practice of the teachers concerning the definition of energy. Therefore, the questionnaire was built by taking account of how energy is actually defined in the French national programs and the selected physics textbooks. It consisted of a few questions focused on how teachers define energy in the frame of their teaching and on their reasons for doing so. Two versions of the questionnaire were produced: one suited for primary teachers, the other for secondary teachers (see Appendices, Table A2). It is important to stress that in France, secondary teachers in physics and chemistry have undergraduate training in science before being trained on science teaching methods, contrary to most primary teachers.

In both versions, the first question (labelled Q1 for primary teachers / Q*1 for secondary teachers) was open and general: ñHow do you describe energy to your students when teaching this concept?ò Teachers had no access to the other questions and accordingly could not be influenced by the information they contain concerning the definition of energy and the property of conservation. In this first question, we chose not to ask expressly for a definition of energy so as to see what teachers were answering spontaneously: they were free to provide a formal definition, and/or a description of the properties of energy, and/or to mention how it may be measured, its unit, and so on. We considered that what they spontaneously mentioned in their answers to this first question are important features of energy according to the 
teachers. When analyzing their answers, we looked if they were spontaneously expressing the following points:

- a nominal definition of energy, and especially a definition in line with Rankine;

- an operational definition of energy (i.e., reference to the way energy is measured, to its units);

- the conservation of energy;

- some difficulty to define energy.

The other questions were closed-ended. We asked explicitly whether they make use of a definition in line with Rankine (without mentioning the name ñRankineò, which is probably not known from most teachers) $\left(\mathrm{Q}^{2} / \mathrm{Q}^{*} 2\right)$, and whether they tell their students that energy is a conserved quantity (Q5 / $\left.\mathrm{Q}^{*} 6\right)$. In the case of a positive answer to these questions, we wanted to know if teachers consider them important and useful elements of the description of energy in their teaching. We avoided asking them directly this by means of a question such as ñls it an important feature of energy in your teaching? Ò with a Likert scale, because the word ñmportantò is rather subjective. Instead, to assess this point, we asked if these are features of energy their ñstudents must write down in their science (resp. physics and chemistry) notebooks and must memorize,ò or ñwhich [they] provide to [their] students only in discussion and which they do not need necessarily to memorizeò $\left(\mathrm{Q}^{2} / \mathrm{Q}^{*} 3\right)$. They could also provide a free answer.

In the case of a negative answer to these questions, we wanted to know teachersôreasons for not introducing these features. When asking them why they do not introduce a definition of energy in line with Rankine (Q4 / Q*5), we anticipated possible reasons (partly based on the literature): ñit does not help students to understand what energy is,ò ñt is too abstract,ò and ñyou did not know this definition.òThey could also provide a free answer. When asking them why they do not introduce the conservation of energy $(\mathrm{Q} 7 / \mathrm{Q} * 8)$, we anticipated other possible reasons (also partly based on the literature): ñstudents cannot understand it,òn ñt is not an item of the programò (in the case of primary school and grades 7 to 9), ñyou did not know this propertyò (in the case of primary teachers) or ñthere are many items in the program and it is not a priority to discuss this propertyò (in the case of secondary teachers). Again, they could also provide a free answer.

\subsection{Outcomes, part 2}

The questionnaire was submitted electronically to primary teachers and secondary teachers in physics and chemistry throughout France. In the case of the primary teachers, the questionnaire was submitted through the intermediary of school inspectors in 12 regional education authorities to an indeterminate number of schools. The number of answers was $N=$ 61. Note that, in practice, energy is not taught by all teachers; those who answered this questionnaire may be only those who actually teach energy. In the case of the secondary teachers, the questionnaire was submitted by means of a mailing list with about 1500 subscribers. The number of responses was $N=116$ (32 teaching in grades 7 to 9 , and 84 in grades 11 and 12).

The answers have been gathered automatically by means of the software used to submit the questions, and transferred into a spreadsheet. The free answers to the first open question were 
analyzed manually according to the grid presented in section 3.3, while the answers to the closed-ended questions were processed statistically so as to yield percentages.

Let us consider first the answers of the primary teachers. When asked whether they provide their students an adapted version of Rankineôs definition, i.e., ñenergy is what is necessary to heat, to light, to set in motion,ò (Q2), 90\% answer ñyes.ò Among those answering ñyes,ò a majority consider it an important element of the description of energy to provide in primary school: $54.5 \%$ of these teachers ask their students to write it down in their science notebooks and to memorize it; whereas the others only mention it in discussion. When analyzing their answers to the first open question (Q1), we observe that $42 \%$ of these teachers spontaneously mention a nominal definition in line with Rankineôs definition and say that they introduce it in their teaching of energy (see examples in Table 2). When expressing this definition, few of them mention the notion of capacity or the system with which energy is associated. Among the teachers who answer that they do not provide their students with an adapted version of Rankineôs definition, one-third consider it too abstract, one-third consider that it does not help students to understand what energy is, and the remaining one-third did not know this definition.

When asked whether they tell their students that energy is conserved (Q5), 29.5\% of the primary teachers answer ñyes.ò Remember that energy conservation is not an item of the primary school programs. Among those answering ñyes, ò a minority consider it an important element of the description of energy to provide in primary school: only $27 \%$ of these teachers ask their students to write it down in their science notebooks and to memorize it, whereas the majority only mention it in discussion. When analyzing their answers to the first open question (Q1), we observe that none of the primary teachers spontaneously mentions conservation of energy as being part of their description of energy in their teaching. Among the teachers who answer that they do not mention it to their students, 37\% argue that it is out of the scope of primary students, $28 \%$ answer that it is not an item of the program of primary school, and $44 \%$ admit that they did not know this property.

Moreover, in their answers to the first open question (Q1), no teacher provided an operational definition of energy; there was no reference to the fact that energy can be measured only indirectly and no mention of the unit of energy.

Note finally that some teachers propose nominal definitions of energy that is not in full agreement with the scientific concept; some confuse energy with force or power or describe it as a type of fuel (which may correspond to a chosen teaching strategy, i.e., describing energy as a quasi-material substance, see Duit, 1987). Some teachers answer that energy is difficult to describe (see examples in Table 2).

Table 2

Selection of some teachers answers to the open question on the description of energy

\begin{tabular}{|c|c|}
\hline \multicolumn{2}{|c|}{ Open question: How do you describe energy to your students when teaching this concept? } \\
\hline Answers of primary teachers (extracts) & $\begin{array}{c}\text { Answers of secondary teachers in physics and } \\
\text { chemistry (extracts) }\end{array}$ \\
\hline Adapted versions of Rankineâ definition: & Rankineô definition or adapted versions of it: \\
\hline
\end{tabular}




\begin{tabular}{|c|c|}
\hline $\begin{array}{l}\text { ñEnergy is necessary in order to move, to heat, to } \\
\text { light.ò } \\
\text { ñEnergy is the source of motion, heat or light.ò } \\
\text { ñóElementô which enables producing motion, heat, } \\
\text { light.ò } \\
\text { ñThat which enables producing workò } \\
\text { ñPossibility (invisible capacity) of a system to } \\
\text { produce work (a force?) that enables moving, } \\
\text { transforming itself, to create heat, light, electricity.ò }\end{array}$ & $\begin{array}{l}\tilde{n} \text { Capacity of a system to cause moving, deformation, } \\
\text { or to produce light or heatò } \\
\text { ñQuantity which enables quantifying the capacity of a } \\
\text { system to move, to heat, to radiateò } \\
\tilde{n} \text { A body has energy if it can produce workò } \\
\text { ñAbility to produce an effect such as to lift or to } \\
\text { accelerate an object, to increase the temperature, to } \\
\text { make electricity flowé ò }\end{array}$ \\
\hline \multirow[t]{2}{*}{$\begin{array}{l}\text { Conservation of energy: } \\
\text { No teacher refers spontaneously to conservation. }\end{array}$} & $\begin{array}{l}\text { Conservation of energy: } \\
\tilde{n} \text { A physical quantity which is conservedò } \\
\tilde{n} A \text { physical quantity for which one cannot give a } \\
\text { definition, but which is always conserved on condition } \\
\text { that the system is correctly definedò } \\
\tilde{n} \text { As Lavoisier tells it, which can be applied to the } \\
\text { principle of energy conservation: óvothing is lost, } \\
\text { nothing is created, all is transforming ̂̂ }\end{array}$ \\
\hline & $\begin{array}{l}\text { Energy defined as belonging to the field of mechanics, } \\
\text { in relation to work (without being associated with } \\
\text { Rankineâs definition): } \\
\text { ñlt is the work of a forceò } \\
\text { ñEnergy is all that is related to mechanical workò } \\
\text { ñln relation to the notion of workò }\end{array}$ \\
\hline $\begin{array}{l}\text { Other types of description or definition: } \\
\text { ñI describe it in terms of energy renewable or not, of } \\
\text { transformations, of pollution.ò } \\
\text { ñTool for comfortò } \\
\text { ñThese are the elements which enable living or not } \\
\text { living beings (machine) to work.ò } \\
\text { ñEnergy is something which allows motion.ò }\end{array}$ & \multirow{2}{*}{$\begin{array}{l}\text { Other types of description or definition: } \\
\tilde{n} \text { A áhingô associated with an object, which it can } \\
\text { exchange, accumulate, loseé ò } \\
\text { ñQuantity [which is] the product of power x timeò } \\
\text { ñSomething which always changes its formò } \\
\text { ñSomething which is exchangedò } \\
\text { ñtt is a quantity which enables quantifying the motion, } \\
\text { the position or the state of a system.ò } \\
\tilde{n} \text { Energy is not an object. Energy is an abstract concept } \\
\text { created by scientists to describe various situations.ò }\end{array}$} \\
\hline $\begin{array}{l}\text { Non-scientific definitions of energy: } \\
\text { ñEnergy is a force which enables to obtain light or } \\
\text { sound.ò } \\
\text { ñIt is a force which enables to move, to transform, to } \\
\text { produce something.ò } \\
\text { ñEnergy is a type of ófuelô which allows a set in } \\
\text { motion, an action.ò }\end{array}$ & \\
\hline $\begin{array}{l}\text { Energy is difficult to describe: } \\
\text { ñI do not address this topic because I do not have } \\
\text { enough knowledge.ò } \\
\text { ñI do not describe it, there are several energies. Fossil, } \\
\text { renewable, natural, artificialé ò }\end{array}$ & $\begin{array}{l}\text { Energy is difficult to describe/define or cannot be } \\
\text { described/defined: } \\
\text { ñIt is very complicated to define.ò } \\
\tilde{n} \text { Energy is a concept and therefore cannot be } \\
\text { ólescribedôò } \\
\text { ñI do not discuss energy in general, but tackle along } \\
\text { the program the energies related to motion, to } \\
\text { electrical current, to nuclear reactionsé ò } \\
\text { ñAs varied as there are forms of energy. No definition } \\
\text { of energy áloneố }\end{array}$ \\
\hline
\end{tabular}

Let us turn now to the answers of the secondary teachers. When asked whether they provide their students Rankineôs definition in terms of changes $\left(Q^{*} 2\right), 26 \%$ answer ñyesò $(37.5 \%$ in middle school, $21 \%$ in high school). Among those answering ñyes,ò a minority consider Rankineôs definition an important element of the description of energy to provide in 
secondary school, whereas $67 \%$ only mention it in discussion without necessarily expecting their students to memorize it. When analyzing their answers to the first open question $\left(\mathrm{Q}^{*} 1\right)$, we observe that $43 \%$ of these teachers spontaneously mention Rankineô definition as being part of their description of energy in their teaching (see examples in Table 2). A majority of them express the definition in terms of ñchanges, ò whereas the others express it in terms of ñwork.ò Most of the teachers providing Rankineôs definition answer that they take time in their teaching to discuss its meaning either by providing examples of ñeffectsò a system can produce by virtue of its energy $(83 \%)$ and/or by explaining that the term ñcapacityò means that these ñeffectsò are only potential or possible (43\%). Among the teachers who answer that they do not provide their students with Rankineôs definition, 53\% consider it too abstract, $40 \%$ feel that it does not help students to understand what energy is, and 39\% did not know this definition.

When asked whether they tell their students that energy is conserved $\left(Q^{*} 6\right), 94 \%$ of the secondary teachers answer ñyesò (without a significant difference between middle and high school teachers). Remember that energy conservation is not an item of the middle school programs. Among those answering ñyes, ò a majority consider it an important element of the description of energy to provide in secondary school: $81.5 \%$ of these teachers ask their students to write it down in their physics and chemistry notebooks and to memorize it, whereas the others only mention it in discussion. However, when analyzing their answers to the first open question $\left(\mathrm{Q}^{*} 1\right)$, we observe that only $21 \%$ of these teachers (without a significant difference between middle and high school teachers) spontaneously mention conservation of energy as being part of their description of energy in their teaching (see examples in Table 2).

Moreover, in their answers to the first open question $\left(\mathrm{Q}^{*} 1\right)$, few secondary teachers $(7 \%)$ provide an operational definition of energy by referring to the fact that energy can be measured only indirectly and/or by mentioning the unit of energy.

Finally, one can observe that some secondary teachers answer that energy is difficult to define or cannot be defined. Several teachers explain that they do not define it, but only introduce the forms of energy in the different parts of the program (see examples in Table 2).

\subsection{Discussion of the outcomes}

As expected, this survey shows a lack of consistency in the way energy is defined throughout schooling. More precisely, the outcomes reveal trends with respect to the approach being favored. In primary school, Rankineôs approach (which consists of providing Rankineôs definition or an adaptation of it) is favored by the programs, by most of the textbooks and by most of the teachers. In middle school, Rankineôs approach remains favored by the programs, but only some textbooks and some teachers are following the programs; other textbooks and teachers favor the conservation approach (which amounts to emphasizing merely the conservation property), although conservation is not an item of the programs. In high school, Rankineôs definition is mentioned neither by the programs nor by the textbooks, but some teachers nonetheless make use of it. In grade 11, the conservation approach is favored by the programs, the textbooks and a majority of teachers.

In brief, in the early grades, an adapted version of Rankineô definition is provided to students and conservation is ignored, while in the last grades, conservation is put forward and 
Rankineôs definition is ignored. We can observe here a lack of ñ et al., 2015, p. 2) with respect to the question of how to define energy: the definition of energy is not r̂́built incrementallyò (ibid.); energy is not given a more sophisticated definition across school years (for instance, first Rankine $\hat{Q}$ definition, then Rankineôs definition and conservation); rather, students are taught a different definition (i.e, first Rankineô definition, then conservation). It is likely that this lack of consistency causes difficulties to students and hinders their understanding of energy.

The lack of curricular coherence may be avoided to some extend if the authors of the national programs are the same for all the grades. This seems to be the case, for instance, with the US Next Generation Science Standards (NGSS Lead States, 2013), which describe the teaching progression for ñdisciplinary core ideasò, including energy, from kindergarten to high school. Nevertheless, this document neither provides a formal nominal definition of energy, at any grade (the item called ñdefinitions of energyò referring to the definitions of the various forms of energy and not to a general definition of energy), nor does it indicate explicitly that such a definition should be excluded. Accordingly, nothing prevents some textbooks and teachers at some grades to introduce a nominal definition of energy. Without a strong commitment of the national programs in favor of a specific teaching progression regarding the definition of energy, the curricular coherence seems difficult to secure.

\section{Toward a coherent teaching progression with regard to energy definition}

We propose to address this consistency problem by investigating the way energy could be defined in a coherent manner across school years. Given the fact conservation is a fundamental property of energy we exclude the option of a teaching progression putting aside this property. Broadly speaking, two main options remain possible: one that focuses on conservation and does never introduce Rankineôs definition, and another that introduces both Rankineôs definition and conservation. Let us discuss the advantages and inconveniences of each of them.

\subsection{Option with conservation only}

Consider first a teaching progression stressing conservation and ignoring Rankineôs definition. It is important to recall that the principle of energy conservation is very difficult for students to master (as noted in several studies: Duit, 1981, Driver \& Warrington, 1985, Solomon, 1985, Trumper, 1990, Neumann et al., 2013). Why is this the case? Several explanations have been advanced. First, the everyday meaning of the concept of energy appears to be in contradiction with the idea of conservation. In everyday life, the energy used to make an object work (e.g., a lamp or a car) seems to vanish; in everyday language, energy refers to something which can be ñproducedò and ñconsumedò (Duit, 1981, Lijnse, 1990, Solomon, 1983, 1985, Vince \& Tiberghien, 2002, Authors, 2014c). Hence, students face two different ways to address and to think about the term ñenergy.ò Second, to understand energy conservation fully requires the integration of many other ideas (Lee \& Liu, 2010). These ideas include not only transformation and transfer of energy but also of dissipation (Duit, 1984, Solomon, 1985, Goldring \& Osborne, 1994, Neumann et al., 2013, Duit, 2014, Lacy et al., 2014) and the distinction between the system under study and its environment (Trellu \& Toussaint, 1986, Arons, 1999, van Huis \& van den Berg, 1993, Jewett, 2008a). Third, 
according to some authors, mastering the principle of energy conservation implies also mastering mathematical equations (Warren, 1982, 1991).

How should these learning difficulties be considered? At least three sub-options are conceivable within the frame of the conservation approach. The first one amounts to deferring teaching energy until after secondary school (or even after high school). This is the option supported by Warren $(1982,1991)$, who argues that the concept should be taught only when students have mastered the mathematical tools that allow them to apply the principle of conservation of energy. However, this option appears as a negation of the very idea of a teaching progression for energy. Moreover, it allows studentsômisconceptions to set in and become ingrained, being unchallenged at an earlier age.

The second option consists of developing a teaching progression for energy that postpones the study of the principle of conservation to the end of this progression. This is the option favored more recently by Neumann et al. (2013); first, teaching should focus on the sources and forms of energy (and avoid confusion between both features), then the ideas of transformation and transfer of energy should be studied, and eventually the ideas of dissipation and conservation should be taught. However, such a teaching progression faces at least three problems. First, if no formal definition of energy is provided to students, they may rely on their initial conceptions, which thereby are more likely to persist. Recall that most initial conceptions of energy are in disagreement with the scientific concept and, in particular, with the conservation principle (Watts, 1983, Duit, 1984, Gilbert \& Pope 1986, Trumper, 1993). Second, according to the teaching progression suggested by Neumann and his colleagues, the forms of energy should be taught before the notion of transformation and hence, in a first step, independently of it. The intention of these authors is understandable; they propose to decompose the conceptual system associated with energy, which is very complex, and to teach its elements step by step. However, to describe phenomena in terms of ñforms of energyò without considering the transformations of these forms of energy seems to be somehow useless; doing so does not help to explain or predict phenomena. In the history of the concept of energy, physicists did not first identify various forms of energy and then discovered possible transformations of them. Instead, they first observed processes connecting different types of phenomena (e.g., electricity and movement, or movement and heat), viewing them as ñconversion processes; Ò then they attempted to make sense of such processes in terms of the transformation of a quantity conserved during these conversions, named ñenergyò (Kuhn, 1959, Elkana, 1974, Harman, 1982, Smith, 2003). To avoid this problem, an alternative teaching progression could consist of introducing both notions of form and transformation of energy from the beginning. This is what Colonnese et al. (2012) proposed in their teaching progression from primary to secondary school. Neumann and his colleagues face a third problem; according to their teaching progression, the fundamental feature of energy, namely its conservation, is only introduced at the end. Consequently, until the last part of their school years, students are somehow blind; they must make use of energy without being told of the feature supposed to give meaning to the concept.

A third option within the frame of the conservation approach, which escapes the last problem, amounts to introducing the conservation property in primary school but qualitatively. This is the option supported by Colonnese and her colleagues, who argue it is important, at this level, to ñlay the groundwork for a more quantitative treatment of energy in 
later studies in middle and high schoolò (2012, p. 27). This option is also favored by Lacy et al. (2014), who contend that conservation is at the core of the ñenergy lens, ò that is, the lens through which scientists examine phenomena and that students must integrate. Recall that the empirical study presented in section 3 highlights that some primary teachers $(29.5 \%$ in our study) indeed choose to hint at the conservation property to their students. A problem with this option nevertheless is that understanding the notion of conservation implies understanding a whole set of other notions, as stressed above, which makes the learning task very ambitious for young students, even in the frame of a qualitative approach. In line with this view, $37 \%$ of the primary teachers of our study who do not introduce conservation consider it as out of the scope of their students.

\subsection{Option with conservation and Rankinê̂ definition}

Let us turn now to a teaching progression introducing both conservation and Rankineôs definition. More precisely, a coherent teaching progression with respect to the definition of energy could then consist in introducing Rankineôs definition at primary school, making use of it all along the school years, and introducing conservation in the second or last part of the school years. For reasons discussed in section 2.3, we will consider here Rankineôs definition in terms of ñchangesò (rather than in terms of ñworkò). The formulation of this definition could be adapted and become more sophisticated across grade levels.

What are the advantages of providing students with Rankineôs definition throughout schooling? At the early grades, students are developing conceptions of energy that are scientifically incorrect (as mentioned above). Explaining to them that their conceptions are incorrect (e.g., energy is not a substance, energy is not a forceé ) without proposing another one might not be sufficient to help them removing these initial conceptions. In this respect, introducing Rankineôs definition in an adapted manner can be very helpful: it is a possible substitute to studentsô erroneous conceptions. Note that Liu and McKeough (2005) have performed an empirical study showing that students can develop an understanding of such a definition at grades 3 and 4 .

At high school, when no formal definition of energy is told to students, most of them tend to conceive energy only in relation to one domain of physics, for instance, as a type of force (in relation to mechanics) or as molecular agitation (in relation to the study of heat) (Authors, 2014c). This leads to the ñ compartmentalizationò problem (Papadouris \& Constantinou, 2016, p. 120, see also Jewett, 2008c, p. 210): students may consider that energy is a quantity relevant only in one domain (e.g., mechanics) and ignore the unifying role of energy (see section 2.4). One possible consequence is that students confuse the principle of energy conservation with the conservation of mechanical energy (which holds only in the specific case without friction) and therefore do not apply the principle correctly (Authors, 2014c). A means to avoid the compartmentalization problem and its consequences is to make use of Rankineôs definition. As stressed in section 2.3, this definition has a very wide scope: it can be applied in all domains of physics. Indeed, the physical changes a system can produce by virtue of its energy can be, for instance, variation of its speed, emission of light, variation of the temperature of a body, change in its physical state, or a mechanical deformation. Considering this definition and studying its meaning might help students become aware of the unifying role of energy. 
However, there is also a disadvantage from the fact that Rankineôs definition in terms of ñchangesò is a general definition: it may appear very abstract to students. Recall that this is the main reason why a majority of secondary teachers do not make use of this definition, according to our case study. The three notions involved in Rankinế definition $\ddot{i}$ change, system and capacity $\ddot{i}$ might all contribute to its abstractness.

Let us consider them one by one and discuss possible strategies for avoiding the abstractness for which they are responsible. The notion of change is itself very general. One can think of two strategies to make this notion less abstract. First, teachers should not provide their students with the definition of energy as ñthe capacity of a system to produce changesò without giving them various examples of changes. In fact, according to our case study, most teachers introducing Rankineôs definition in secondary school provide examples of changes to their students. Another possibility amounts merely to avoiding use of the word ñchangeò and to providing directly a list of examples of changes. Perhaps this second solution is best suited for students in primary school, whereas the first option is preferable for students in secondary school. Note that the textbooks and teachersôanswers analyzed in our case study are in accordance with such a progression.

The notion of system is also an abstraction, which consists of isolating mentally a part of the physical world to model its properties and the relationships with its environment. A teaching progression with respect to this notion is also conceivable. The word ñsystemò could be included in Rankineôs definition only in a second step, in secondary school. In a first step, in primary school, the word ñsystemò could be avoided. Two options remain possible. The very notion of system (and not only the word ñsystemò) could be set aside (e.g., ñEnergy is what is needed to set in motion, to heat, or to lightò). Alternatively, teachers could express the definition for specific cases of systems that are well known by the students (e.g., ñA lamp needs energy to lightò).

Finally, the notion of capacity is perhaps the most abstract and the most difficult for students to understand: to say that energy is the capacity of a system to produce changes means that it is a p̃potentialò property (McIldowie, 2004), in other words, it refers to changes which could be produced under certain conditions. If the term ñcapacityò is used, it seems important to discuss with students what it means. According to our study, almost half of the secondary teachers using the word when they introduce Rankine $\hat{\theta}$ definition explain the meaning of the term ñcapacity.ò In primary school, the term ñ capacityò is most likely too difficult to understand even when explained by teachers. A means to avoid using the term ñcapacityò without misrepresenting Rankine $\hat{Q}$ definition consists for instance of using the word ñallow:Ò ñEnergy is what allows something to make changes. For example, energy is what allows a car to set in motion, a radiator to heat, or a lamp to light.ò In secondary school, when the notion of system has been introduced, a definition as follows can be given: r̃Energy is what makes a system able to produce physical changes, such as setting in motion, heating or lighting.ò

In this teaching progression, the principle of energy conservation is not at all ruled out. One can well consider that both Rankineôs definition and energy conservation are essential features of the teaching of energy. The discussion in section 4.1 suggests that the property of conservation should be introduced either in middle or high school: previously, students must have acquired knowledge concerning the forms of energy (to be distinguished from the 
sources of energy), transformations and transfers of energy (to be distinguished from the forms of energy), as well as an understanding of the system/environment distinction, and their ñcognitive maturationò (Liu \& McKeough, 2005) must allow them being able to combine all these features of energy and to make use of mathematical equations. Rankineôs definition of energy can be useful at this point. As stressed above, it may help students becoming aware of the unifying role of energy, and consequently applying more properly the principle of energy conservation: by not reducing it to the conservation of mechanical energy, and by taking into account all the forms and transfers of energy in a given situation.

\section{Conclusion}

In this paper, we first examined what physics can tell us on the question of how to define energy. We identified and discussed two main approaches: the conservation approach and Rankineôs approach. We then investigated if one or both of these approaches is actually endorsed in schools in the case of France. This study brought to light a consistency problem in the way energy is defined across school years. Indeed, in primary school, in accordance with the French national programs, most teachers introduce an adapted version of Rankineôs definition and put aside conservation. In high school, it is the other way round: still in accordance with the national programs, most teachers introduce conservation and ignore Rankineôs definition.

This study has been carried out by means of a questionnaire. Yet, there might be some discrepancy between what teachers answered and their actual teaching practices. So as to get a more faithful picture of how energy is defined in schools, we could make observations in classrooms at all the grades and look at what teachers are actually telling their students. However, there would be the practical problem of making such observations in a sufficiently significant number of classrooms. Besides, we performed a case study, in one country only. A similar study could be performed in various countries in order to determine the extent of the consistency problem.

In the last part of the paper, we addressed the consistency problem by discussing two ways energy could be defined throughout schooling: one that focuses on conservation and does never introduce Rankineôs definition, and another that introduces both Rankineôs definition and conservation. We stressed that a problem with the conservation approach is that it leaves students without any formal definition of energy, which can lead them to rely on their initial erroneous conceptions. We came to argue in favor of the second option. For, at primary school, an adapted version of Rankineôs definition offers a possible substitute to studentsô erroneous conceptions. At secondary school, this definition can help students become aware of the unifying role of energy and thereby overcome the compartmentalization problem, which may hinder proper application of the principle of energy conservation.

Eventually, the main recommendation we make in this paper at variance with the French national programs and teachersôdeclared practice is to make use of Rankineôs definition in secondary school, especially in high school. Although we made several proposals for teachers so as to avoid the abstractness of this definition, we did not provide concrete examples of teaching lessons introducing it. To assess the effectiveness of making use of Rankineôs definition in high school, new teaching sequences could be built, implemented and tested. We 
believe that the question of how to define energy across school years is an important one with respect to the teaching and learning of energy and deserves to be investigated further.

\section{References}

Arons, A. (1999). Development of energy concepts in introductory physics courses. American Journal of Physics, 67(12), 1063-1067.

Authors (2014a).

Authors (2014b).

Authors (2014c).

Bunge, M. (2000). Energy: between physics and metaphysics. Science \& Education, 9, 457461.

Chen, R., Eisenkraft, A., Fortus, D., Krajcik, J., Nordine, J. \& Scheff, A. (eds.) (2014). Teaching and learning of energy in K-12 education. Cham, Heidelberg, New York, Dordrecht, London: Springer.

Coelho, R. (2014). On the concept of energy: eclecticism and rationality. Science \& Education, 23, 1361 ï 1380.

Colonnese, D., Heron, P., Michelini, M., Santi, L. \& Stefanel, A. (2012). A vertical pathway for teaching and learning the concept of energy. Review of Science, Mathematics and ICT Education, 6(1), 21-50.

Doménech, J.-L., Gil-Pérez, D., Gras-Marti, A., Guisasola, J., Martínez-Torregrosa, J., Salinas, J., Trumper, R., Valdés, P. \& Vilches, A. (2007). Teaching of energy issues: a debate proposal for a global reorientation. Science \& Education, 16, 43 ï 64.

Driver, R. \& Warrington, L. (1985). Studentô use of the principle of energy conservation in problem situation. Physics Education, 5, 171-175.

Duit, R. (1981). Understanding energy as a conserved quantity. European Journal of Science Education, 3(3), 291-301.

Duit, R. (1984). Learning the energy concept in school: empirical results from the Philippines and West Germany. Physics Education, 19, 59-66.

Duit, R. (1987). Should energy be introduced as something quasi-material? International Journal of Science Education, 9, 139-145.

Duit, R. (2014). Teaching and learning the physics energy concept. In Chen et al. (pp. 67-85).

Eisenkraft, A., Nordine, J., Chen, R., Fortus, D., Krajcik, J., Neumann, K. \& Scheff, A. (2014). Introduction: why focus on energy instruction? In Chen et al. (pp. 1-11).

Elkana, Y. (1974). The discovery of the conservation of energy. London: Hutchinson Educational LTD.

Feynman, R. (1963). The Feynman lectures on physics, vol. I: mainly mechanics, radiation, and heat. California Institute of Technology.

Fortus, D., Sutherland Adams, L., Krajcik, J. \& Reiser, B. (2015). Assessing the role of curriculum coherence in student learning about energy. Journal of Research in Science Teaching, 52(10), 1408ї 1425.

Galili, I. \& Lehavi, Y (2006). Definitions of physical concepts: a study of physics teachersô knowledge and views. International Journal of Science Education, 28(5), 521-541.

Gilbert, J. \& Pope, M. (1986). Small group discussions about conception in science: a case study. Research in Science and Technological Education, 4, 61-76. 
Goldring, H. \& Osborne, J. (1994). Studentsôdifficulties with energy and related concepts. Physics Education, 29(1), 26 ï 32.

Harman, P. (1982). Energy, force and matter: the conceptual development of nineteenthcentury physics. Cambridge: Cambridge University Press.

Hobson, A. (2004). Energy and work: the meaning of energy. The Physics Teacher, 42(5), 260.

Jewett, J. (2008a). Energy and the confused student II: systems. The Physics Teacher, 46(2), 81-86.

Jewett, J. (2008b). Energy and the confused student III: language. The Physics Teacher, 46(3), 149-153.

Jewett, J. (2008c). Energy and the confused student IV: a global approach to energy. The Physics Teacher, 46(4), 210-217.

Joule, J. (1845). On the existence of an equivalent relation between heat and the ordinary forms of mechanical power. Philosophical Magazine, series 3, 27, 205-207.

Joule, J. (1847). On the mechanical equivalent of heat, as determined by the heat evolved by the friction of fluids. Philosophical Magazine, series 3, 31, 173-176.

Kuhn, T. (1959). Energy conservation as an example of simultaneous discovery. In M. Clagett (ed.), Critical Problems in the History of Science (pp. 321-56). Madison (Wis.): The University of Wisconsin Press.

Lacy, S., Tobin, R.G., Wiser, M. \& Crissman, S. (2014). Looking through the energy lens: a proposed teaching progression for energy in grades 3-5. In Chen et al. (pp. 241-265).

Lee H.-S. \& Liu O. (2010). Assessing learning progression of energy concepts across middle school grades: the knowledge integration perspective. Science Education, 94(4), 665-688.

Lehavi, Y., Eylon, B., Hazan, A., Bamberger, Y. \& Weizman, A. (2012). Focusing on changes in teaching about energy. Proceedings of the World Conference on Physics Education 2012, WCPE. Pegem Akademi.

Lijnse, P. (1990). Energy between the life-world of pupils and the world of physics. Science Education, 74(5), 571-583.

Liu, X. \& McKeough, A. (2005). Developmental growth in studentsô concept of energy: analysis of selected items from the TIMSS database. Journal of Research in Science Teaching, 42(5). 493-517.

Margenau, H. (1950). The nature of physical reality. New York: McGraw-Hill.

McIldowie, E. (2004). A trial of two energies. Physics Education, 39(2), 212-214.

Millar, D. (2005). Teaching about energy. Department of Educational Studies: research paper 2005/11. Retrieved from: http://www.york.ac.uk/media/educationalstudies/documents/research/Paper11Teachingabo utenergy.pdf.

National Research Council (1996). National Science Education Standards. Washington, DC: National Academy Press.

Neumann K., Viering T., Boone W. \& Fischer H. (2013). Towards a learning progression of energy. Journal of Research in Science Teaching, 50(2), 162-188.

Next Generation Science Standards (2013)

NGSS Lead States (2013). Next Generation Science Standards: for states, by states. Washington, DC: The National Academies Press. 
Nordine J, Krajcik J. \& Fortus D. (2011). Transforming energy instruction in middle school to support intergrated understanding and future learning. Science Education, 95(4), 670-699.

Papadouris, N. \& Constantinou, C. (2011). A philosophically informed teaching proposal on the topic of energy for students aged 11-14. Science \& Education, 20, 961-979.

Papadouris, N. \& Constantinou, C. (2016). Investigating middle school studentsôability to develop energy as a framework for analyzing simple physical phenomena. Journal of Research in Science Teaching, 53(1), 119-145.

Quinn, H. (2014). A physicistôs musings on teaching about energy. In Chen et al. (pp. 15-36).

Rankine, W. (1855). Outlines of the science of energetics. The Edinburgh New Philosophical Journal, July-October 1855, Vol. II, 3, 121-141.

Sexl, R. (1981). Some observations concerning the teaching of the energy concept. European Journal of Science Education, 3(3), 285-289.

Smith, C. (2003). Force, energy, and thermodynamics. In M. J. Nye (ed.), The Cambridge history of science: the modern physical and mathematical sciences (pp. 289-310). Cambridge: Cambridge University Press.

Solomon, J. (1983). Learning about energy: how pupils think in two domains. European Journal of Science Education, 5, 49-59.

Solomon, J. (1985). Teaching the conservation of energy. Physics Education, 20, 165-170.

Trumper, R. (1990). Being constructive: an alternative approach to the teaching of the energy concept, part one. International Journal of Science Education, 12(4), 343-354.

Trumper, R. (1991). Being constructive: an alternative approach to the teaching of the energy concept, part two. International Journal of Science Education, 13(1), 1-10.

Trumper, R. (1993). Childrenô energy concepts: a cross-age study. International Journal of Science Education, 15, 139-148.

Van Huis, C. \& van den Berg, E. (1993). Teaching energy: a systems approach. Physics Education, 28, 146-153.

Vince, J. \& Tiberghien, A. (2012). Enseigner lấnergie en physique à partir de la question sociale du défi énergétique. Review of Science, Mathematics and ICT Education, 6(1), 89124.

Warren, J. (1982). The nature of energy. European Journal of Science Education, 4(3), 295297.

Warren, J. (1991). The teaching of energy. Physics Education, 26(1), 8-9.

Watts, D. (1983). Some alternative views of energy. Physics Education, 18, 213-217. 


\section{Appendices}

Table A1

The programs and textbooks analyzed in the study

\section{The French national programs}

MEN (Ministère de lâEducation nationale, France). (2008a). Programmes dâenseignement de lấcole primaire, Bulletin Officiel de lôEducation Nationale, hors série $n^{\circ} 3$ du 19 juin 2008.

MEN. (2008b). Programmes du collège : programmes de lậnseignement de physique-chimie. Bulletin Officiel de lấEducation Nationale, spécial n 6 du 28 août 2008.

MEN (2010). Programme dônseignement spécifique de physique-chimie en classe de première de la série scientifique. Bulletin Officiel de lâEducation Nationale, spécial nº 4 des 9 et 30 septembre 2010.

MEN (2011). Programme de lâenseignement spécifique et de spécialité de physique-chimie, classe terminale de la série scientifique. Bulletin Officiel de lâEducation Nationale, spécial nº 8 du 13 octobre 2011.

MEN (2012). Progressions pour le cours élémentaire deuxième année et le cours moyen, sciences expérimentales et technologie. Bulletin Officiel de lđ̊ducation Nationale, 5 janvier 2012.

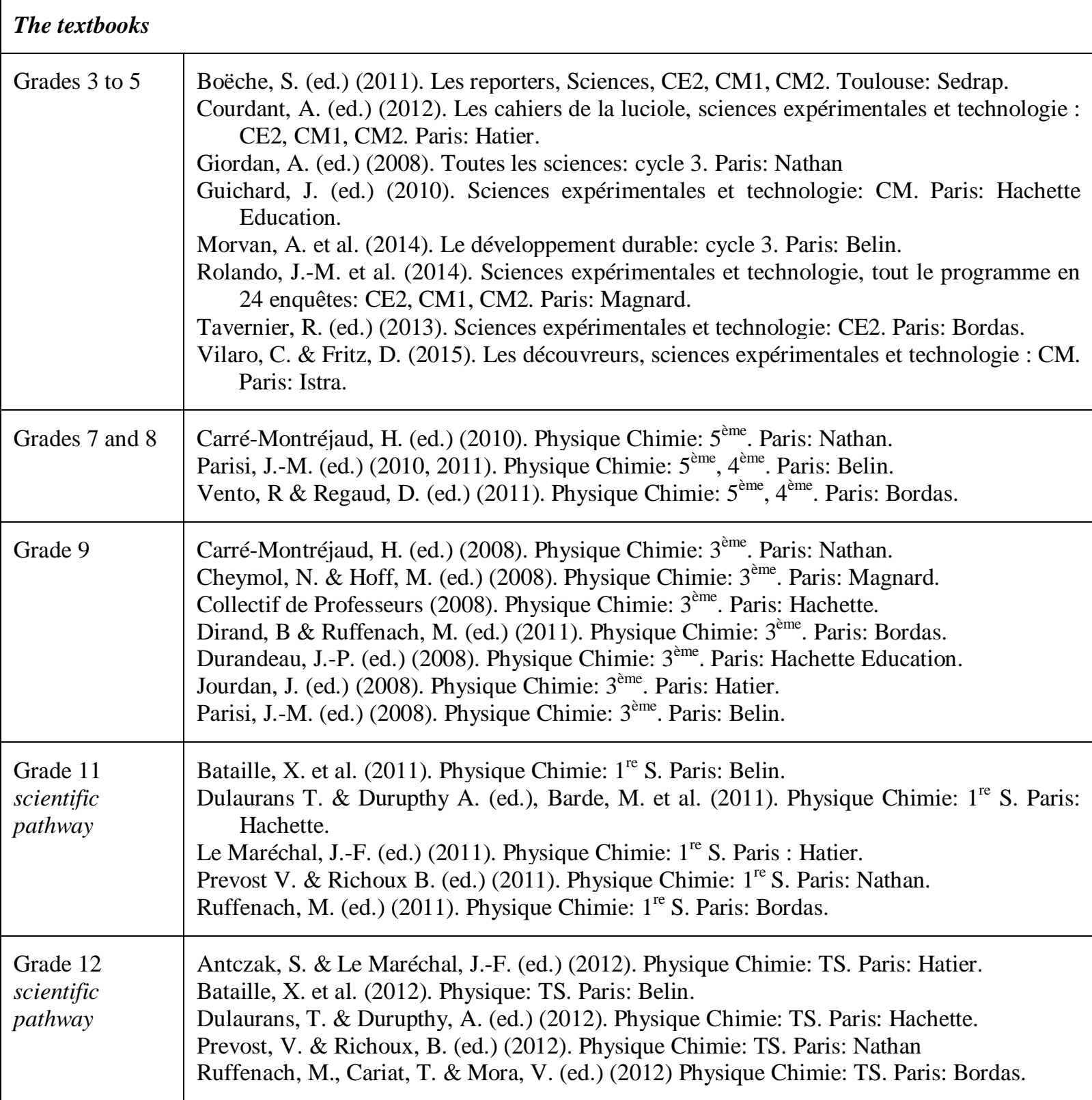


Table A2

The two versions of the questionnaire submitted to the teachers

\begin{tabular}{|c|c|}
\hline Questionnaire submitted to primary teachers & $\begin{array}{l}\text { Questionnaire submitted to secondary teachers in } \\
\text { physics and chemistry }\end{array}$ \\
\hline $\begin{array}{l}\text { Q1: How do you describe energy to your students } \\
\text { when teaching this concept? }\end{array}$ & $\begin{array}{l}\text { Q*1: How do you describe energy to your students } \\
\text { when teaching this concept? }\end{array}$ \\
\hline $\begin{array}{l}\text { Q2: Do you tell your students that energy is what is } \\
\text { ñnecessary so as to heat, to light, to set in motionò } \\
\text { (quotation from the national program of 2012)? } \\
\text { yes / no }\end{array}$ & $\begin{array}{l}\text { Q*2: Do you tell your students that energy is ñthe } \\
\text { capacity of a system to produce an effectò (quotation } \\
\text { from the national program of 2008)? } \\
\text { yes / no }\end{array}$ \\
\hline $\begin{array}{l}\text { If teachers answered yes to Q2: } \\
\text { Q3: The definition of energy as what is ñnecessary so } \\
\text { as to heat, to light, to set in motionò is a definition: } \\
\text { A1: your students must write down in their science } \\
\text { notebooks and must memorize. } \\
\text { A2: which you provide to your students only in } \\
\text { discussion and which they do not need necessarily to } \\
\text { memorize. } \\
\text { A3: other answer: é }\end{array}$ & $\begin{array}{l}\text { If teachers answered yes to } Q * 2 \text { : } \\
\text { Q*3: The definition of energy as ñthe capacity of a } \\
\text { system to produce an effectò is a definition: } \\
\text { A1: your students must write down in their physics } \\
\text { and chemistry notebooks and must memorize. } \\
\text { A2: which you provide to your students only in } \\
\text { discussion and which they do not necessarily need to } \\
\text { memorize. } \\
\text { A3: other answer: é } \\
\text { Q*4: When you express this definition: } \\
\text { (several answers can be given) } \\
\text { A1: you provide examples of ñeffectsò a system can } \\
\text { produce by virtue of its energy (e.g., set in motion, } \\
\text { increase in temperature, deformationé ). } \\
\text { A2: you explain that the term ñcapacityò means that } \\
\text { the ñeffectsò (a system can produce by virtue of its } \\
\text { energy) are only potential or possible. } \\
\text { A3: I do not take time to explain it. } \\
\text { A4: other answer: é }\end{array}$ \\
\hline $\begin{array}{l}\text { If teachers answered no to Q2: } \\
\text { Q4: You do not provide the definition of energy as } \\
\text { what is ñnecessary so as to heat, to light, to set in } \\
\text { motionòbecause: } \\
\text { (several answers can be given) } \\
\text { A1: it does not help students to understand what } \\
\text { energy is. } \\
\text { A2: it is too abstract. } \\
\text { A3: you did not know this definition. } \\
\text { A4: other answer: é }\end{array}$ & $\begin{array}{l}\text { If teachers answered no to } \mathbf{Q 2 :} \\
\mathbf{Q}^{* 5} \text { : You do not provide the definition of energy as } \\
\text { ñthe capacity of a system to produce an effecto } \\
\text { because: } \\
\text { (several answers can be given) } \\
\text { A1: it does not help students to understand what } \\
\text { energy is. } \\
\text { A2: it is too abstract. } \\
\text { A3: you did not know this definition. } \\
\text { A4: other answer: é }\end{array}$ \\
\hline $\begin{array}{l}\text { Q5: Do you tell your students that energy is conserved } \\
\text { (or can be neither created nor destroyed)? } \\
\text { yes / no }\end{array}$ & $\begin{array}{l}\text { Q*6: Do you tell your students that energy is } \\
\text { conserved (or can be neither created nor destroyed)? } \\
\text { yes / no }\end{array}$ \\
\hline $\begin{array}{l}\text { If teachers answered yes to Q5: } \\
\text { Q6: Conservation of energy is a property: } \\
\text { A1: your students must write down in their science } \\
\text { notebooks and must memorize. } \\
\text { A2: which you provide to your students only in } \\
\text { discussion and which they do not need necessarily to } \\
\text { memorize. } \\
\text { A3: other answer: é }\end{array}$ & $\begin{array}{l}\text { If teachers answered yes to } Q^{* 6} \text { : } \\
\mathbf{Q}^{* 7:} \text { Conservation of energy is a property: } \\
\text { A1: your students must write down in their physics } \\
\text { and chemistry notebooks and must memorize. } \\
\text { A2: which you provide to your students only in } \\
\text { discussion and which they do not necessarily need to } \\
\text { memorize. } \\
\text { A3: other answer: é }\end{array}$ \\
\hline
\end{tabular}


If teachers answered no to Q5:

Q7: You do not introduce conservation of energy because:

(several answers can be given)

A1: primary students cannot understand it.

$A 2$ : it is not an item of the program of primary school.

A3: you did not know this property.

A4: other answer: é
If teachers answered no to $Q * 6$ :

Q*8: You do not introduce conservation of energy because:

(several answers can be given)

A1: your students cannot understand it.

$A 2$ : it is not an item of the program (if you teach in grades 7 to 9 ).

A3: there are many items in the program and it is not a priority to discuss this property.

A4: other answer: é 